\title{
PENGARUH RISK BASED BANK RATING TERHADAP FINANCIAL DISTRESS PADA BUSN NON DEVISA
}

\author{
Rista Nurfadila Pristianti \\ Universitas Negeri Surabaya \\ ristanurfadilapristianti@gmail.com \\ Musdholifah Musdholifah \\ Universitas Negeri Surabaya \\ musdholifah@unesa.ac.id
}

\begin{abstract}
Banking health is very important to be maintained because banks play an important role in society, especially as increasing the country's economic growth. This study aims to examine the effect of risk-based bank rating on financial distress. The risk-based bank rating ratio consists of risk profiles proxied by NPL and LDR, good corporate governance proxied by the size of the board directors and independent commissioners, earnings proxied by ROA, ROE, BOPO, and NIM, and capital proxied by CAR. The yardstick used in this research is the bankometer model. The research year is 6 years from 2013-2018. The population was all non-foreign exchange banks, amounting to 30. The sample was determined using purposive sampling, find 20 non-foreign exchange with data analysis techniques using logistic regression. Research data using SPSS 25. The results of the study found the influence of LDR, size of the board directors, NIM, and CAR. LDR ratio has a significant negative effect, board size has a significant positive effect, NIM has a significant negative effect, and CAR has a significant negative effect on financial distress. This because the fourth variable had an important thing on liquidity, independent oversight, interest income, and capital adequacy. Whereas NPL, independent commissioners, ROA, ROE, and BOPO do not affect financial distress. This because the value of each variable already appropriate with Bank Indonesia determination and it summed up that Non-Foreign Exchange Bank already apply it well. This shows that risk-based bank ratings can be a parameter of bank health.
\end{abstract}

Keywords: bankometer model; financial distress; non-foreign exchange bank; risk-based bank rating.

\section{PENDAHULUAN}

Kesehatan suatu perbankan sangatlah penting untuk tetap dijaga karena bank memegang peranan penting dalam masyarakat terutama sebagai menaikkan pertumbuhan ekonomi negara. Akibat peranan tersebut, sektor perbankan yang berfungsi dengan baik sangat penting untuk perkembangan ekonomi dan menjaga stabilitas sistem keungan (John \& Ogechukwu, 2018). Financial distress diartikan turunnya perihal finansial bank dengan konsekuensi apabila tidak bisa keluar dari kondisi ini maka akan mengalami kebangkrutan (Nufus et al., 2018). Rahman (2017) mengartikan kondisi financial distress sebagai kondisi keadaan kacau balau bank yang akhirnya bank tersebut akan menunjukkan kondisi tertekan sebelum akhirnya mengalami likuidasi. Sofiasani \& Gautama (2016) berpendapat financial distress penting untuk diketahui oleh perusahaan dalam rangka melaksanakan sikap mengantisipasi terjadinya kesulitan keuangan yang parah. Menurut Ramadhani (2019) financial distress dapat dilihat dari beberapa indikator seperti analisis arus kas, analisis strategi bank, dan laporan keuangan tahunan.

Kegentingan moneter yang timbul pada 1997 di Asia Tenggara akibat lunturnya kepercayaan investor atas mata uang Asia mengakibatkan krisis global yang terparah. Salah satu akibat yang ditimbulkan adalah nilai tukar mata uang banyak yang terdevaluasi, terutama Indonesia hingga 90\% (ekbis.sindonews, 2018). Selanjutnya, krisis yang diakibatkan oleh kredit macet pada sektor properti (subprime mortgage) di Negeri Paman Sam pada 2008 sebagai konsekuensi mudahnya pemberian kredit rumah kepada debitur yang tidak layak membuat sektor perbankan menerima dampak yang besar karena kredit properti membuat perusahaan pembiayaan tidak kuasa menyanggupi keharusan kepada lembagalembaga keuangan sehingga likuiditas dan sistem keuangan bank tergolong buruk (ekbis.sindonews, 2018). Dampaknya lembaga keuangan mengalami pengeringan likuiditas sehingga memicu terjadinya kebangkrutan. 
Rista Nurfadila Pristianti \& Musdholifah. Pengaruh Risk Based Bank Rating terhadap Financial Distress pada BUSN Non Devisa

Beberapa krisis tersebut juga berdampak pada kondisi perbankan di tanah air. Kegentingan tahun 1997 menyebabkan 16 bank dilikuidasi akibat kesulitan keuangan (financial distress). Dampak krisis pada tahun 2008 menyebabkan sistem perbankan dan keuangan Indonesia mengalami keadaan genting serta terdapat potensi mengalami capital flight. Selain itu, Bank Century mengalami kondisi keuangan yang parah hingga Lembaga Penjamin Simpanan mengeluarkan bail-out 6,76 Trilliun demi menyelamatkan bank tersebut karena dikhawatirkan menimbulkan systemic risk dan rush dalam sistem perbankan nasional (economy.okezone, 2010).

Perkara yang acap muncul dalam perbankan ialah likuiditas, di mana terlihat dari nilai Loan to Deposit Ratio (LDR). Bank Indonesia menganjurkan, batas bawah LDR adalah $72 \%$ dan batas atas $92 \%$ (Kristanti, 2014). Prasidha \& Wahyudi (2015) mengartikan Loan to Deposit Ratio (LDR) kecakapan bank dalam menyanggupi kewajiban jangka pendek maupun jangka panjang. Tercatat sepanjang tahun 2018 dan 2019, LDR perbankan melampaui margin ketetapan BI yakni 94\% dan 94,98\% (cnnindonesia.com, 2019). Nilai LDR yang dibiarkan melebihi 92\% dikhawatirkan akan menurunkan dana cadangan atau secondary reserve yang berdampak profitabilitas bank turun sehingga mengalami financial distress semakin tinggi.

Penyebab financial distress salah satunya perusahaan tidak dapat mempertahankan kinerjanya sehingga tidak kuasa berdampingan dengan perusahaan-perusahaan lain sehingga perusahaan tersebut dipastikan tergusur dalam lingkungan industri (Assaji \& Machmuddah, 2017). Faktor lain yang perlu diamati agar terhindar dari financial distress adalah kondisi kesukaran modal, beban hutang tinggi, dan mengalami defisit berkepanjangan (Halim, 2016). Diawali dengan ketidakmampuan perusahaan memenuhi kewajibannya, penundaan pembayaran tagihan, menurunnya kualitas produk/ jasa menjadi suatu pertanda bahwa perusahaan sedang mengalami kesulitan keuangan (Sadida, 2018).

Kegiatan bank yang berlebihan, akan membuahkan risiko yang semakin besar (Nuranto \& Ardiansari, 2017). Risiko kredit menjadi risiko perbankan yang tidak dapat dihindari dengan ditunjukkan oleh nilai Non Performing Loan (NPL). Semakin tinggi perhitungan NPL maka mengalami kondisi kesulitan keuangan dari segi kredit semakin tinggi (Halim, 2016). Kelompok bank persero memiliki nilai NPL yang cukup stabil dengan rata-rata nilai NPL berkisar pada nilai 2,3\%. Sedangkan untuk BUSN devisa, BPD, bank campuran, dan bank asing memiliki NPL fluktuatuif dengan pada tahun 2013-2016 mulai adanya peningkatan NPL daripada tahun sebelumnya yang memiliki rata-rata nilai NPL 2,37\%, 3,33\%, $2,38 \%$, dan $1,66 \%$. Lain halnya dengan BUSN non devisa yang mengalami peningkatan nilai NPL dimulai tahun 2013-2014 dengan peningkatan yang terjadi sebesar 0,30\% dan meningkatan untuk tahun-tahun selanjutnya (IDX, 2013-2018). Peningkatan terbanyak terjadi pada tahun 2015-2016 dengan prosentase peningkatan sebesar 1,3\% dan nilai NPL yang sudah melebihi batas atas ketetapan BI yaitu sebesar 4,25\% (IDX, 2013-2018). Hal ini mengindikasikan buruknya nilai NPL BUSN non devisa yang apabila dibiarkan maka kemungkinan terjadinya financial distress akan tinggi.

Dalam menghindari risiko financial distress, suatu perbankan dapat menganalisis laporan keuangan yang dimiliki dengan menggunakan model prediksi (Prasidha \& Wahyudi, 2015). Beberapa penelitian prediksi model financial distress yang dapat digunakan salah satunya adalah Bankometer model. Penelitian yang dilakukan dengan Bankometer model belum banyak dilakukan dan sampel bank yang dipilih masih sangat sedikit (Shar, 2010). Studi yang dilakukan oleh Yamin \& Sami (2016) menunjukkan Bankometer model memberikan penilaian akurat terhadap kondisi kesehatan bank. Sejalan dengan hal tersebut, Kristanti (2014) merekomendasikan penggunaan model ini sebagai analisis kondisi kesehatan bank karena masih sedikit ditemui di Indonesia dan tingkat akurasi mencapai 88\%.

Dalam mengatasi permasalahan financial distress Bank Indonesia mengeluarkan kebijakan perihal tingkat kesehatan bank sebagai acuan dalam menanggulangi persoalan perbankan. Peraturan ini tertuang dalam Surat Edaran Bank Indonesia No. 13/24/DPNP/2011 tentang Penilaian Tingkat Kesehatan Bank yang dengan melihat sisi Risk Based Bank Rating (RBBR). Risk Based Bank Rating (RBBR) menggunakan 4 faktor utama yang dinilai, yaitu risk profile, good corporate governance, earning, dan capital. Signaling theory akan dipergunakan untuk menjelaskan hubungan risk profile, earning, dan capital. Faktor good corporate governance akan dijelaskan dengan Agency theory. 
Indikator risk profile meliputi dua indikator yaitu Non Performing Loan (NPL) dan Loan to Deposit Ratio (LDR). Nilai NPL yang besar mengakibatkan pencadangan perbankan semakin besar, ini membuat oppurtunity cost yang ditanggung baik semakin meningkat sehingga bank mengalami kerugian (Sumantri \& Jurnali, 2010). Sedangkan, nilai LDR yang besar menggambarkan bank dalam kondisi kekurangan likuiditas, dampaknya bank mengalami kekurangan pendapatan yang seharusnya diperoleh dari bank pada saat memberikan kredit terhadap nasabah (Halim, 2016). Penelitian Pasaribu et al., (2015), Prasidha \& Wahyudi (2015), Ramadhani (2019), Shidiq \& Wibowo (2017) berhasil mendeteksi hubungan signifikan NPL dan LDR terhadap financial distress. Akan tetapi, bertentangan dengan penelitian Harahap (2015), Kuncoro \& Agustina (2017), Nufus et al., (2018), Sistiyarini \& Supriyono (2017) menemukan tidak adanya hubungan NPL dan LDR dengan financial distress.

Indeks good corporate governance pada penelitian ini yaitu ukuran dewan direksi dan komisaris independen. Jumlah dewan direksi akan berpengaruh dalam penerimaan perolehan pendapatan sehingga semakin banyak dewan direksi maka pendapatan perusahaan akan semakin untung (Sadida, 2018). Perusahaan yang memiliki dewan komisaris independen tinggi dalam struktur dewan komisaris yang tinggi pula, maka strategi pengecekan berlangsung lebih independen dan terbebas kepentingan pribadi manajer sehingga perusahaan terhindar akan biaya keagenan yang tinggi (Fathonah, 2016). Studi John \& Ogechukwu (2018) dan Murhadi et al., (2018) menjumpai hubungan signifikan ukuran dewan direksi dan komisaris independen terhadap financial distress. Penelitian Radifan et al., (2015), Sadida (2018), Setiawan et al., (2016) tidak berhasil menjumpai hubungan signifikan ukuran dewan direksi dan komisaris independen terhadap financial distress.

Faktor earning di proksikan Return On Asset (ROA), Return On Earning (ROE), Beban Operasional terhadap Pendapatan Operasional (BOPO), dan Net Interest Margin (NIM). Return On Asset (ROA) yang tinggi mengindikasikan bank memiliki pencapaian besar pada keuntungannya dan posisi penggunaan aset dari bank semakin baik (Harahap, 2015). Return On Earning (ROE) yang tinggi menunjukkan bank efisien dalam menggunakan modal sendiri untuk memperoleh keuntungan (Restianti \& Agustina, 2018). Beban Operasional terhadap Pendapatan Operasional (BOPO) yang tinggi menandakan bank tidak efisien dalam penggunaan biaya operasional dibandingkan pendapatan operasional (Sofiasani \& Gautama, 2016). Net Interest Margin (NIM) yang tinggi berdampak baik dari sisi peningkatan pendapatan bunga atas aktiva produktif yang dikelola bank (Asyikin et al., 2018). Penelitian Asyikin et al., (2018), Harahap (2015), Restianti \& Agustina (2018), Sofiasani \& Gautama (2016) mendapatkan hasil hubungan signifikan ROA, ROE, BOPO, NIM terhadap financial distress. Kriswanto (2019) dan Nuranto \& Ardiansari (2017) tidak sependapat dengan hasil tersebut dan tidak menemukan hubungan signifikan.

Faktor capital diproksikan oleh Capital Adequacy ratio (CAR) memegang peranan penting dalam pembiayaan penurunan aset bank oleh ekuitas yang dimiliki (Sadida, 2018). Penelitian Hayati (2018), Hidayati (2015), Sadida (2018) menemukan adanya hubungan signifikan CAR terhadap financial distress. Hasil tersebut tidak di dukung Ramadhani (2019), Sistiyarini \& Supriyono (2017), Theodorus \& Artini (2018) karena tidak menemukan hubungan signifikan CAR terhadap financial distress.

Penelitian ini bertujuan untuk mengetahui pengaruh risk based bank rating terhadap financial distress dengan bankometer model pada BUSN non devisa sebagai sarana peringatan awal sebelum kondisi financial distress terjadi. Hasil penelitian ini diharapkan menjadi sarana pihak yang membutuhkan dalam pengambilan keputusan serta referensi terkait penilaian kondisi perbankan yang mengakami financial distress.

\section{KAJIAN PUSTAKA DAN PENGEMBANGAN HIPOTESIS}

\section{Signalling Theory}

Teori sinyal memiliki pengertian reaksi yang dijalankan oleh manajemen perusahaan untuk menyampaikan pengarahan bagi investor terkait dengan jalan apa manajemen memperhatikan prospek perusahaan (Brigham \& Houston, 2009;440). Menurut Siagian (2010) pihak manajemen akan 
menyampaikan arahan yang relevan sehingga stakeholder memperoleh hasil positif dan keputusan yang diambil sesuai dengan pemahamannya akan sinyal tersebut. Sinyal disini berupa informasi-informasi penting seperti pencapaian manajemen perusahaan terkait terealisasinya keinginan pemilik ataupun keunggulan yang dimiliki perusahaan dibanding perusahaan lainnya. Sehingga data laporan keuangan dapat dijadikan sarana dalam memahami sinyal kegagalan perusahaan (Rahman, 2017).

\section{Agency Theory}

Siagian (2010) menginterpretasikan hubungan keagenan sebagai kontrak yang terjadi dengan satu orang lebih (principal) yang mengikutsertakan orang lain (agent) dalam menjalankan suatu layanan atas nama mereka yang menyertakan perwakilan wewenang terkait pengambilan keputusan kepada agent. Sedangkan menurut Hanafi \& Breliastiti (2016) diartikan pemecahan antara kepemilikan (principal) dan pengelolaan perusahaan (agent) yang mana terdapaat perbedaan proposisi tiap-tiap individu serta hanya termotivasi oleh kepentingan pribadi dan berdampak timbulnya perselisihan kepentingan antara principal dan agent. Penerapan good corporate governance pada teori ini, yakni teori yang menggambarkan interaksi antara manajemen dengan pemilik, di mana manajemen berperan sebagai agen yang berkewajiban menumbuhkan margin para pemilik (principal) dengan imbalan yang diperoleh ialah kompensasi sesuai dengan yang disepakati. Tujuan principal dan agent yang berbeda dapat mengundang perselisihan karena manajer mengarah pada tujuan pribadi. Hal ini berdampak, kinerja manajer tidak fokus dan pendanaan perusahaan yang menghasilkan laba tinggi dalam jangka waktu pendek lebih diutamakan daripada kesejahteraan pemegang saham melalui pendanaan proyek jangka panjang akan tetapi lebih menguntungkan (Siagian, 2010).

\section{Financial Distress}

Kondisi perusahaan yang sedang mengalami masa-masa sulit dalam aspek keuangannya, mulai dari skala ringan sampai dengan skala berat yang selanjutnya dapat mengakibatkan kebangkrutan sering dikenal dengan financial distress (Kurniasari \& Ghozali, 2013). Financial distress juga bisa menjadi suatu sirine bagi perusahaan terkait kondisi keuangan yang tidak seimbang baik yang disebabkan oleh internal perusahaan maupun eksternal. Kondisi keuangan perusahaan yang mengalami financial distress dapat diamati pada neraca perusahaan serta laporan arus kas (Sadida, 2018). Penyebab terjadinya kondisi ini menurut Kriswanto (2019) antara lain (1) Faktor kesulitan modal, tidak seimbangnya antara penjualan atau penagihan piutang lebih kecil daripada beban operasional perusahaan. (2) Beban hutang dan bunga semakin membengkak, semisal perusahaan dirasa berkecukupan menarik dana dari luar maka akan menimbulkan permasalahan lainnya yakni keterikatan tanggung jawab membayar kembali pokok pinjaman dan bunga kredit. (3) Menderita kerugian, bank tidak dapat mengendalikan seluruh biaya yang dikeluarkan sehingga kekayaan bersih perusahaan semakin tergerus.

Sektor bank mampu meminimalisir timbulnya financial distress dengan mengawasi keadaan keuangan yang tercantum pada laporan keuangan (Yacheva et al., 2016). Pengawasan dilakukan menggunakan beberapa teknik analisis laporan keuangan, seperti Altman Z-Score, CAEL, Bankometer model. Penelitian Erari et al., (2013) menemukan bankometer model merupakan teknik analisis terbaik dan akurat dalam mengetahui kondisi bank daripada Altman dan CAEL. Pernyataan tersebut didukung oleh Iqbal et al., (2018) menemukan hasil bankometer model dapat digunakan sebagai parameter yang tepat dalam mengidentifikasi kondisi bank distress dan non-distress. Selain itu, bankometer model merupakan penyempurna dari model sebelumnya (CAMEL, CLSA, VAIC) yang tidak terlalu berhasil dalam mengukur kinerja dan kerentanan perbankan dengan sedikit perubahan terhadap bobot presentase (Shar, 2010). Pengembangan model ini merupakan saran dari International Monetary Fund pada tahun 2000 (IMF, 2000).

Sebagai variabel dependen, financial distress akan diukur dengan parameter Bankometer model (Shar, 2010). Kriteria model adalah apabila S Score memiliki nilai kurang dari 50 dikategorikan financial distress dan memiliki nilai 1, sebaliknya apabila nilai lebih dari 70 atau diantara 50 dan 70 bernilai 0 atau kategori non-financial distress.

$$
\mathrm{S}_{\text {Score }}=1.5 C A+1.2 E A+3.5 C A R+0.6 N P L+0.3 C I+0.4 L A
$$




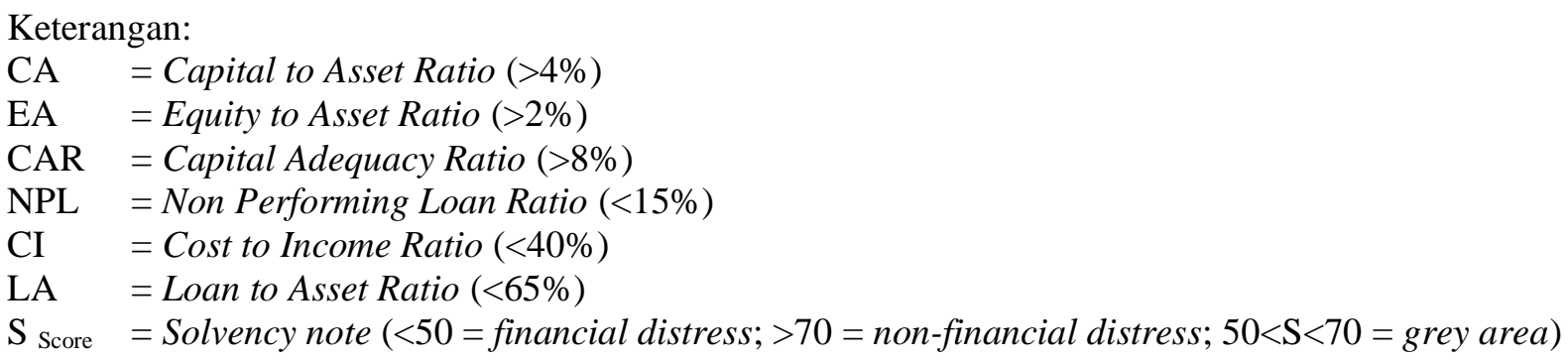

\section{Risk Based Bank Rating}

Surat Edaran Bank Indonesia No. 13/1/PBI/2011terkait Sistem Penilaian Tingkat Kesehatan Bank di mana mewajibkan mengadakan pengukuran tingkat kesehatan melalui pendekatan risiko (Risk Based Bank Rating) secara individual maupun konsolidasi. Dengan pemberlakuan aturan ini, mengakibatkan tergantinya metode sebelumnya yakni metode berdasar atas Capital, Assets, Management, Earning, Liquidity, and Sensitivity atau lebih dikenal dengan CAMELS tidak dipergunakan kembali mulai awal tahun 2012 (Bank Indonesia, 2011). Metode Risk Based Bank Rating (RBBR) memanfaatkan penilaian pada empat faktor, antara lain risk profile, good corporate governance, earning, dan capital.

\section{Risk Profile}

Profil risiko memerankan peranan penting dalam penilaian tingkat bank karena hampir sebagian besar bank yang gagal disebabkan oleh bank tidak dapat mengendalikan risiko-risiko yang terjadi (Hilmy et al., 2013). Penelitian ini menggunakan 2 indikator pengukuran risk profile yaitu risiko kredit dan risiko likuiditas yang diproksikan dengan Non Performing Loan (NPL) dan Loan to Deposit Ratio (LDR). Pemilihan kedua indikator ini dikarenakan berimbas besar pada keadaan perbankan (Pasaribu et al., 2015).

\section{Non Performing Loan (NPL)}

Risiko kredit adalah ketidaksanggupan debitur dalam pelunasan kewajiban pada pihak bank (Halim, 2016). NPL akan menunjukan keahlian manajemen dalam pengelolaan kredit bermasalah dari keseluruhan kredit yang diberikan. Sehingga, semakin tinggi nilai NPL bank akan berdampak pada jumlah kredit bermasalah lebih banyak daripada kredit lancar sehingga menimbbulkan masalah keuangan (Pasaribu et al., 2015; Prasidha \& Wahyudi, 2015; Rahman, 2017; Ramadhani, 2019). NPL membandingkan antara kredit bermasalah dengan total kredit yang diberikan (Yacheva et al., 2016), dengan formula (2).

$$
N P L=\frac{\text { Kredit Bermasalah }}{\text { Total Kredit }} \times 100 \%
$$

\section{Loan to Deposit Ratio (LDR)}

Risiko likuiditas berkaitan dengan kesanggupan pemenuhan kewajiban jangka pendek maupun jangka panjang bank (Hidayati, 2015). LDR digunakan untuk mengukur seberapa bisa dana pinjaman diberikan yang berasal dari dana pihak ketiga. Tingginya rasio LDR, mengindikasikan likuid bank minim dibanding bank yang memiliki nilai rendah (Asyikin et al., 2018; Kurniasari \& Ghozali, 2013). Rasio ini membandingkan antara total kredit yang diberikan dengan total dana pihak ketiga (Yacheva et al., 2016), dengan formula (3).

$$
L D R=\frac{\text { Total Kredit yang Diberikan }}{\text { Total Dana Pihak Ketiga }} \times 100 \%
$$

\section{Good Corporate Governance}

Penerapan good corporate governance ialah kebijakan dalam mengelola perusahaan untuk mempersembahkan nilai lebih kepada pemegang saham dan stakeholders secara berkelanjutan dalam jangka panjang (Hanafi \& Breliastiti, 2016). Tujuan corporate governance tidak lain untuk meminimalisasi perselisihan pihak agent dan principal yang berakibat turunnya agency cost. Indikator yang dipergunakan antara lain ukuran dewan direksi dan komisaris independen. 
Rista Nurfadila Pristianti \& Musdholifah. Pengaruh Risk Based Bank Rating terhadap Financial Distress pada BUSN Non Devisa

Ukuran Dewan Direksi

Dewan Direksi merupakan prosedur corporate governance yang bertugas menetapkan strategi berupa jangka pendek atau jangka panjang (Helena \& Saifi, 2018). Jumlah anggota dewan direksi akan disesuaikan pada kerumitan yang terjadi akan tetapi tetap mengamati efektifitas pengambilan keputusan. Semakin banyak dewan direksi akan mempengaruhi kualitas keputusan yang di ambil sehingga pendapatan bank juga semakin baik (Radifan et al., 2015). Formula perhitungan ukuran dewan direksi adalah menghitung jumah anggota dewan direksi pada periode t (Hanafi \& Breliastiti, 2016).

Komisaris Independen

Komisaris Independen bertanggung jawab memonitor kebijakan dan sikap direksi serta menganjurkan beberapa nasihat baik kepada Dewan Direksi apabila mendesak. Jumlah komisaris independen yang banyak akan semakin baik karena pengendalian penerapan manajemen perusahaan mendapatkan pengawasan dari pihak independen secara penuh (Fadhilah \& Syafruddin, 2013; Fathonah, 2016). Rasio ini membandingkan jumlah anggota dewan komisaris independen dengan jumlah total anggota dewan komisaris (Siagian, 2010), dengan rumus (4).

$$
P D K I=\frac{\text { Jumlah Anggota Dewan Komisaris Independen }}{\text { Jumlah Total Anggota Dewan Komisaris }} \times 100 \%
$$

\section{Earning}

Earning merupakan kemampuan bank dalam menghasilkan profit. Kegunaan earning adalah menilai efisiensi usaha dan profit yang diperoleh bank (Asyikin et al., 2018). Proksi yang digunakan antara lain Return On Asset (ROA), Return On Earning (ROE), Beban Operasional terhadap Pendapatan Operasional (BOPO), dan Net Interest Margin (NIM).

\section{Return On Asset (ROA)}

ROA melambangkan kesanggupan perusahaan yang diukur secara keseluruhan dalam membuahkan keuntungan dari jumlah keseluruhan aktiva yang tersedia (Purwohandoko et al., 2014) . Rasio ini menjadi tolak ukur bank menghasilkan laba dari aset yang ada. Semakin besar nilai ROA, semakin baik kemampuan bank dalam menghasilkan laba (Ramadhani, 2019; Sofiasani \& Gautama, 2016; Theodorus \& Artini, 2018). Rasio ini membandingkan antara laba sebelum pajak dengan rata-rata total aset (Yacheva et al., 2016), dengan formula (5).

$$
R O A=\frac{\text { Laba Sebelum Pajak }}{\text { Rata-rata Total Aset }} \times 100 \%
$$

\section{Return On Earning (ROE)}

ROE dimanfaatkan dalam memperkirakan seberapa besar laba bersih yang dihasilkan dari setiap dana pada ekuitas (Restianti \& Agustina, 2018). Kuantitas rasio ini menggambarkan seberapa efektif modal sendiri untuk menghasilkan laba bersih. Semakin besar nilai ROE maka bank dapat menggunakan modal/ekuitasnya secara efisien (Shidiq \& Wibowo, 2017). Rasio ini membandingkan laba bersih setelah pajak dengan ekuitas atau modal sendiri (Asyikin et al., 2018), dengan rumus (6).

$R O E=\frac{\text { Laba Setelah Pajak }}{\text { Modal Sendiri }} \times 100 \%$

Beban Operasional terhadap Pendapatan Operasional (BOPO)

BOPO berfungsi dalam menilai seberapa mampu pihak manajemen dalam mengelola biaya operasional atas pendapatan operasional (Sofiasani \& Gautama, 2016). Tingginya rasio ini mengindikasikan efisiensi biaya operasional yang dikeluarkan oleh bank gagal yang berimbas pada pendapatan operasional semakin berkurang (Fadhilah \& Syafruddin, 2013; Kurniasari \& Ghozali, 2013). Cara mencari nilai BOPO dengan membandingkan beban operasional terhadap pendapatan operasional (Fadhilah \& Syafruddin, 2013) seperti pada rumus (7).

$B O P O=\frac{\text { Beban Operasional }}{\text { Pendapatan Operasional }} \times 100 \%$ 


\section{Net Interest Margin (NIM)}

NIM digunakan untuk menilai kekuatan aktiva produktif dalam menciptakan pendapatan berupa bunga bersih (Sadida, 2018). Bunga bersih yang diperoleh mengikuti nilai selisih bunga kredit yang disalurkan. Sehingga, semakin besar rasio NIM menggambarkan pendapatan bunga atas aktiva produktif yang dikelola semakin meningkat (Shidiq \& Wibowo, 2017). Formula BOPO adalah perbandingan pendapatan bunga bersih dengan rata-rata aktiva produktif (Yacheva et al., 2016) dengan detail di rumus (8).

$N I M=\frac{\text { Pendapatan Bunga Bersih }}{\text { Rata-rata Aktiva Produktif }} \times 100 \%$

\section{Capital}

Penilaian aspek capital sesuai ketentuan Bank Indonesia, dalam hal ini terlihat pada Capital Adequacy Ratio (CAR). Capital Adequacy Ratio (CAR) menggambarkan kecukupan modal yang mempertunjukkan kemampuan bank mempertahankan modalnya serta kesangupan manajemen dalam mengawasi, mengidentifikasi, mengukur, dan mengontrol risiko-risiko yang bisa mempengaruhi modal inti maupun pelengkap (Kuncoro \& Agustina, 2017). Besarnya nilai CAR mengindikasikan kesanggupan bank semakin baik dalam menahan peluang timbulnya risiko kerugian (Halim, 2016; Hidayati, 2015; Sadida, 2018). Cara menghitung CAR dengan membandingkan modal dengan ATMR (Yacheva et al., 2016), dengan ditemukan formula (9).

$$
C A R=\frac{\text { Modal }}{\text { ATMR }} \times 100 \%
$$

\section{Hubungan Antar Variabel}

Berdasarkan signaling theory, laporan keuangan memberikan sinyal positif ataupun negatif terkait nilai NPL bagi stakeholder. Informasi tersebut berisi tentang kondisi kredit bermasalah sehingga kredit bermasalah yang tinggi akan memberikan sinyal negatif terhadap stakeholder (Ramadhani, 2019). Kredit bermasalah atau macet bermula dari dana yang diberikan oleh bank kepada debitur yang tidak bisa mengembalikan dana tersebut, sehingga menimbulkan pembiayaan bermasalah yang besar dan membuat bank mengalami financial distress (Halim, 2016). Tingginya nilai NPL membuat semakin tinggi kemungkinan mengalami financial distress sehingga adanya hubungan positif signifikan terhadap financial distress (Halim, 2016; Pasaribu et al., 2015; Prasidha \& Wahyudi, 2015; Ramadhani, 2019). Hasil tersebut dibantah oleh Hilmy et al., (2013), Shidiq \& Wibowo (2017) dengan menemukan adanya hubungan negatif signifikan dengan alasan bank hanya memberikan kredit kepada dana pihak ketiga bukan kredit terhadap bank lain sehingga manajemen bank memiliki cukup dana untuk disisihkan yang membuat risiko kredit untuk gagal kecil sehingga kemungkinan financial distress semakin kecil.

H1: Adanya pengaruh antara variabel risk profile yang diproksikan dengan NPL terhadap financial distress pada BUSN non devisa.

Loan to Deposit Ratio (LDR) melambangkan rasio likuiditas untuk memperkirakan jumlah dana dalam bentuk kredit yang bersumber pada dana pihak ketiga (Halim, 2016). Nilai LDR menggambarkan kondisi repayment penarikan dana yang dilakukan deposan sehingga apabila nilai LDR bank tinggi maka nasabah dapat menerima sinyal negatif dari perbankan karena tidak dapat melakukan pengembalian dana. Akan tetapi, nilai LDR terlalu rendah juga merugikan bank karena pendapatan bank sebagian besar berasal dari penyaluran kredit meskipun akhirnya bank tergolong dalam memiliki likuiditas yang cukup memadai (Sumantri \& Jurnali, 2010). Sehingga pihak manajemen dituntut untuk menjaga nilai LDR dengan skala 78\%-94\%. Penelitian Asyikin et al., (2018) Hidayati (2015), Kurniasari \& Ghozali (2013), Pasaribu et al., (2015) menemukan hasil positif signifikan LDR terhadap financial distress dengan argumentasi tingginya nilai LDR membuat tingginya kredit bermasalah yang akan mengurangi pendapatan bunga bersih sehingga mengalami financial distress juga tinggi. Alasan yang dikemukakan bertolak belakang dengan temuan negatif signifikan penelitian Sumantri \& Jurnali (2010), Susanto \& Njit (2012) dengan dalih nilai LDR rendah diartikan besaran kredit yang dialokasikan oleh bank rendah namun dana yang dihimpun tinggi, ini mengakibatkan bank memiliki 
Rista Nurfadila Pristianti \& Musdholifah. Pengaruh Risk Based Bank Rating terhadap Financial Distress pada BUSN Non Devisa

dana yang berlebih apabila nasabah ingin menarik uangnya kembali sehingga kepercayaan nasabah akan bank terjaga dan kemungkinan mengalami financial distress kecil.

$\mathrm{H} 2$ : Adanya pengaruh antara variabel risk profile yang diproksikan dengan NPL terhadap financial distress pada BUSN non devisa.

Dewan direksi menggambarkan agen yang posisinya sebagai penyelenggara dengan merujuk pada intruksi yang disampaikan oleh pemilik (Radifan et al., 2015). Dewan direksi seringkali memiliki perbedaan pendapatan dengan manajemen terkait penerimaan investasi jangka pendek ataupun panjang yang membuat timbulnya agency problem. Agency problem yang berkelanjutan akan menimbulkan agency cost yang dapat merugikan bank sehingga bank tidak memperoleh profit secara maksimal (Harahap, 2015). Studi yang dikerjakan Radifan et al., (2015) menjumpai hubungan negatif signifikan artinya semakin banyak ukuran direksi dapat memastikan pengawasan dan pelaksanaan internal perusahaan dengan baik sehingga kinerja perusahaan meningkat dan bank mengalami financial distress semakin rendah. Berlawanan dengan hasil tersebut, Helena \& Saifi (2018) serta Setiawan et al., (2016) mendapatkan hubungan positif signifikan artinya banyaknya jumlah dewan direksi membuat fungsi dewan direksi dalam pengambilan keputusan terkait pengelolaan aset perusahaan tidak berjalan dengan optimal, dewan direksi hanya akan disibukkan oleh masalah koordinasi dan komunikasi.

H3: Adanya pengaruh antara variabel good corporate governance yang diproksikan dengan ukuan dewan direksi terhadap financial distress pada BUSN non devisa.

Kontribusi serta eksistensi komisaris independen sebagai supervisory board dalam stuktur menjadi vital untuk menyeleksi ataupun memantau setiap langkah yang digapai oleh direktur (executive board) (Fadhilah \& Syafruddin, 2013). Komisaris independen yang rendah akan membuat mekanisme pengawasan tidak efektif sehingga kemungkinan adanya asymmetric information antara principal dan agent juga akan semakin besar dan berkelanjutan. Ini membuat fungsi independensi komisaris independen tidak berjalan dengan baik sehingga pihak ekternal akan meragukan kinerja dari perbankan (Helena \& Saifi, 2018). Banyaknya proporsi komisaris independen akan mempengaruhi terkait tata kelola perusahaan yang baik dan bank terhindar dari financial distress. Temuan tersebut menunjukkan adanya hubungan negatif signifikan komisarism independen terhadap financial distress (Fadhilah \& Syafruddin, 2013). Hal ini bertentangan dengan penemuan John \& Ogechukwu (2018) yang mendapatkan hubungan positif signifikan dengan alasan komisaris independen yang terlalu banyak tidak akan berkontribusi positif terhadap kemajuan bank karena banyak dari komisaris independen kurang mengetahui secara mendalam terkait cara kerja internal bank.

H4: Adanya pengaruh antara variabel good corporate governance yang diproksikan dengan komisaris independen terhadap financial distress pada BUSN non devisa.

Return On Asset (ROA) berdasarkan pandangan Brigham \& Houston (2009) ialah rasio yang digunakan untuk memperkirakan kesanggupan manajemen untuk mengantongi pendapatan terhadap total asset. Semakin besar rasio Return on Assets (ROA) akan berdampak semakin besar surplus yang didapat sehingga semakin baik posisi bank dari segi penggunaan asset dan kecil kemungkinan menjumpai financial distress. Penggambaran yang terjadi ialah adanya hubungan negatif signifikan ROA terhadap financial distress dengan hubungan ini di dukung Harahap (2015), Rahman (2017), Sofiasani \& Gautama (2016). Penelitian Sumantri \& Jurnali (2010) menemukan hubungan positif signifikan dengan berpendapat meskipun laba bank turun, akan tetapi total asset yang terjaga dengan tetap tinggi dan penempatan pada BI yang meningkat dari sisi asset lancar akan membuat bank mengalami financial distress kecil.

H5: Adanya pengaruh antara variabel earning yang diproksikan dengan ROA terhadap financial distress pada BUSN non devisa.

Return On Equity (ROE) dapat diartikan dengan tolak ukur laba bersih dengan modal yang dimiliki bank (Kurniasari \& Ghazali, 2013). Tingginya rasio ROE mengindikasikan pemanfaatan modal sendiri 
dalam menghasilkan keuntungan semakin efisien sebaliknya apabila rasio ini rendah maka pemanfaatan modal sendiri dalam menghasilkan laba tidak efisien, sehingga bank berpotensi mengalami financial distress. Temuan yang mendukung adanya hubungan negatif ROE terhadap financial distress antara lain Asyikin et al., (2018), Restianti \& Agustina (2018). Sedangkan, Susanto \& Njit (2012) menjumpai hubungan positif signifikan dengan alasan bank mampu memperoleh laba yang cukup untuk membayar deviden kepada investor, akan tetapi terdapat kebijakan yang diberlakukan oleh pemerintah pada tahun tersebut dengan akibat yang timbul menderita distress semakin besar.

H6: Adanya pengaruh antara variabel earning yang diproksikan dengan ROE terhadap financial distress pada BUSN non devisa.

Biaya Operasional terhadap Pendapatan Operasional (BOPO) menggambarkan perbandingan antara biaya operasi dengan pendapatan operasi yang diperoleh (Theodorus \& Artini, 2018). Nilai BOPO yang tinggi menunjukkan sinyal negatif pada pihak eksternal dengan menunjukkan bank tidak bisa meminimalisasi biaya operasionalnya dan berefek perolehan pendapatan bank semakin kecil. Semakin tinggi BOPO, menunjukkan rendahnya efisiensi operasional bank sehingga aktiva bank dalam menghasilkan keuntungan tidak secara optimal maka adanya hubungan positif signifikan BOPO terhadap financial distress (Asyikin et al., 2018; Sofiasani \& Gautama, 2016). Temuan berbeda didapatkan penelitian Shidiq \& Wibowo (2017), Theodorus \& Artini (2018) dengan alasan meskipun rasio BOPO tinggi dan menghambat laba yang diperoleh bank akan tetapi bank dapat mencari sumber dana lainnya sehingga dapat menutupi laba yang seharusnya diperoleh sehingga adanya hubungan negatif signifikan BOPO terhadap financial distress.

H7: Adanya pengaruh antara variabel earning yang diproksikan dengan BOPO terhadap financial distress pada BUSN non devisa.

Nilai NIM yang rendah akan memberikan sinyal negatif terhadap pihak eksternal terkait pengelolaan aktiva produktif bank dengan tidak bisa membuahkan pendapatan bunga bersih secara maksimal sehingga nasabah tidak akan percaya bahwa bank dapat mengembalikan dananya yang masih disaurkan dalam bentuk kredit. Rasio NIM memaparkan terkait efisiensi pengelolaan aktiva bersih serta pendapatan bunga (Prasidha \& Wahyudi, 2015). Tingginya rasio ini akan berdampak terhadap laba bunga atas aktiva produktif yang di kelola juga meningkat sehingga peluang mendapati financial distress kecil. Hasil ini didukung oleh Asyikin et al., (2018), Sadida (2018), Shidiq \& Wibowo (2017) menemukan adanya hubungan negatif signifikan. Berbanding terbalik dengan Sumantri \& Jurnali (2010) menemukan hubungan positif signifikan NIM terhadap financial distress.

H8: Adanya pengaruh antara variabel earning yang diproksikan dengan NIM terhadap financial distress pada BUSN non devisa.

Capital Adequacy Ratio (CAR) ialah alat ukur yang dimanfaatkan untuk mengetahui berapa jumlah aktiva bank yang mengandung risiko dengan dibiayai oleh modal sendiri (Kurniasari \& Ghozali, 2013). Nilai rasio CAR yang tinggi memiliki arti tingginya kekuatan bank dalam memikul risiko yang dihadapi, sebaliknya penurunan rasio ini akan membuat nasabah kehilangan kepercayaan terhadap bank sehingga dapat mengancam keberlangsungan usah bank (Sadida, 2018). Adanya hubungan negatif signifikan didukung oleh penelitian Halim (2016), Hidayati (2015), Kuncoro \& Agustina (2017). Hubungan tersebut bertentangan dengan penelitian Hayati (2018) yang menemui hubungan positif signifikan dengan alasan rasio CAR yang terlalu tinggi menunjukkan bahwa perluasan atau investasi yang dilakukan pada aktiva yang berisiko dalam memperoleh pendapatan bank tidak berjalan maksimal, sementara itu rendahnya nilai CAR juga memiliki dampak buruk karena bank tidak dapat memenuhi pembayaran investasi pada aktiva berisiko dengan modal sendiri.

H9: Adanya pengaruh antara variabel capital yang diproksikan dengan CAR terhadap financial distress pada BUSN non devisa. 
Rista Nurfadila Pristianti \& Musdholifah. Pengaruh Risk Based Bank Rating terhadap Financial Distress pada BUSN Non Devisa

\section{METODE PENELITIAN}

Penelitian yang dilakukan termasuk jenis penelitian eksplanatif, dengan alasan memiliki hasil akhir gambaran mengenai hubungan sebab dan akibat antara variabel risk based bank rating dengan variabel financial distress. Pengumpulan data memanfaatkan teknik dokumentasi data sekunder dalam laporan keuangan tahunan BUSN non devisa. Sumber data diperoleh dari website resmi BUSN non devisa. Periode penelitian selama 6 tahun yang dimulai 2013 sampai 2018. Populasi yang diambil adalah keseluruhan BUSN non devisa yang berdasarkan data OJK sebesar 30 bank. Pemilihan sampel dipilih dengan teknik purposive sampling. Kriteria sampel penelitian ini antara lain (1) Bank umum swasta nasional non devisa yang menerbitkan laporan tahunan (annual report) secara berturut-turut periode 2013-2018, (2) Sampel tidak melakukan merger ataupun akuisisi pada periode 2013-2018. Hasil akhir diperoleh sampel penelitian sebanyak 20 bank. Analisis regresi logistik dipilih sebagai teknik analisis data, karena pencampuran skala pada variabel independen membuat penelitian ini tidak memerlukan asumsi normalitas (Ghozali, 2018;325). Program SPSS 25 akan membantu dalam proses pengolahan. Beberapa teknik analisis data yang akan diaplikasikan antara lain menilai model fit, koefisien determinasi, uji kelayakan model, uji keakuratan regresi, dan uji estimasi parameter (Ghozali, 2018;322-328).

\section{HASIL DAN PEMBAHASAN}

Tabel 1. MODEL SUMMARY

\begin{tabular}{crrrr}
\hline Step & $\begin{array}{c}-\mathbf{2} \text { Log } \\
\text { likelihood }\end{array}$ & $\begin{array}{c}\text { Cox \& Snell R } \\
\text { Square }\end{array}$ & $\begin{array}{c}\text { Nagelkerke R } \\
\text { Square }\end{array}$ & $\begin{array}{c}\text { Hosmer and } \\
\text { Lemeshow Test }\end{array}$ \\
\hline 0 & 114.339 & .424 & .690 & .628 \\
1 & 48.162 & & & \\
\hline
\end{tabular}

Sumber: Output SPSS (2020, data diolah)

\section{Menilai Model Fit}

Dari Tabel 1, diketahui nilai statistik -2LogL yang hanya konstanta tanpa variabel (block number 0) memiliki nilai sebesar 114,339 dan nilai -2LogL setelah ditambahkan 9 variabel baru (block number 1) maka nilai -2LogL turun menjadi 48,162. Hal ini menandakan terjadinya penurunan sebesar 66,177 $(114,339$ - 48,162). Penurunan yang terjadi dapat dikatakan signifikan dengan dibandingkan pada nilai tabel df. Nilai tabel df didapatkan dari nilai df1 $=120-1=119$, df $2=120-9=111$, sehingga selisih $\mathrm{df}$ yang didapatkan df $3=119-111=8$. Bersumber pada tabel chi square dengan df 8 dengan signifikansi 0,05 didapatkan nilai 15,507313. Oleh karena nilai 66,177 lebih besar daripada tabel df $(66,177>$ 15,507313) maka dapat dikatakan selisih penurunan -2LogL signifikan. Sehingga menerima H0, artinya penambahan variabel independen risk based bank rating (NPL, ukuran dewan direksi, komisaris independen, LDR, ROA, ROE, BOPO, NIM, CAR) kedalam model dapat membetulkan model fit.

\section{Koefisien Determinasi}

Tabel 1 memperlihatkan nilai 0.690 untuk negelkerke $R$ square, mengandung pengertian variabilitas variabel bebas yaitu NPL, ukuran dewan direksi, komisaris independen, LDR, ROA, ROE, BOPO, NIM, CAR dapat menjelaskan variabilitas variable dependen yaitu financial distress dalam model regresi logistik sebesar 69,0\% dengan 31,0\% sisanya dijelaskan oleh variabel bebas lainnya.

\section{Uji Kelayakan Model}

Dari Tabel 1, uji hosmer and lemeshow's mengungkapkan hasil signifikan sebesar 0.628 sehingga menerima H0 karena nilai signifikan yang diperoleh melebihi $0.05(0.628>0.05)$. Artinya, tidak terdapat perbedaan antara model dengan data yang diamati sehingga model dikatakan layak.

\section{Uji Keakuratan Regresi}


Tabel 2 menunjukkan terdapat 98 bank non financial distress yang diobservasi, di mana 93 bank diprediksi tidak mengalami financial distress dan 5 bank mengalami financial distress. Maka diperoleh tingkat akurasi sebesar 0.949 atau $94.9 \%$. Disamping itu diketahui pula terdapat 22 sampel bank financial distress yang diobservasi, dengan 7 bank diprediksi tidak mengalami financial distress dan 15 bank mengalami financial distress, dengan akurasi klasifikasi ialah 0.682 atau 68.2\%. Artinya, keseluruhan tingkat ketepatan klasifikasi bankometer model pada penelitian ini adalah 90,0\%.

\section{Tabel 2. \\ TABEL KLASIFIKASI}

\begin{tabular}{llrrr}
\hline & \multicolumn{3}{c}{ Observed } & Predicted \\
& & & Percentage Correct \\
\hline Y Non FinDes & Non FinDes & 93 & 5 & 94.9 \\
& FinDes & 7 & 15 & 68.2 \\
Overall Percentage & & & 90.0 \\
\hline
\end{tabular}

Sumber: Output SPSS (2020, data diolah)

Tabel 3.

HASIL REGRESI LOGISTIK

\begin{tabular}{ccccc}
\hline & B & S.E. & Wald & Sig. \\
\hline (Constant) & 12.310 & 5.969 & 4.254 & .039 \\
LDR & -.132 & .048 & 7.514 & .006 \\
UK DEDIR & .915 & .314 & 8.494 & .004 \\
KOM INDP & -.360 & 3.271 & .012 & .912 \\
ROA & .337 & .443 & .579 & .447 \\
ROE & .046 & .053 & .761 & .383 \\
BOPO & .031 & .028 & 1.220 & .269 \\
NIM & -.310 & .147 & 4.441 & .035 \\
CAR & -.469 & .140 & 11.305 & .001 \\
NPL & .330 & .226 & 2.139 & .144 \\
\hline
\end{tabular}

Sumber: Output SPSS (data diolah, 2020)

\section{Uji Estimasi Parameter dan Interpretasi}

$\operatorname{Ln} \frac{\mathrm{p}}{1-\mathrm{p}}=12.310-0.132 \mathrm{LDR}+0.915 \mathrm{UK}$. DEDIR $-0.310 \mathrm{NIM}-0,469 \mathrm{CAR}+\mathrm{e}$

Persamaan regresi logistik (9) diperoleh berdasarkan tabel 3. Berdasarkan persamaan (9), variabel LDR, ukuran dewan direksi, NIM, dan CAR signifikan pada 0.05. Dapat diketahui setiap kenaikan satu LDR menurunkan log of odds bank yang mengalami financial distress sebesar 0.132. Apabila ukuran dewan direksi, NIM, dan CAR dianggap konstan, lalu log of odds bank yang mengalami financial distress naik menjadi 0.915, karena nilai $\beta$ positif. Setiap kenaikan satu ukuran dewan direksi meningkatkan $\log$ of odds bank yang mengalami financial distress sebesar 0.915. Jika LDR, NIM, dan CAR dianggap konstan, maka log of odds bank yang mengalami financial distress turun menjadi 0.310, karena nilai $\beta$ negatif. Setiap kenaikan satu NIM menurunkan log of odds bank yang mengalami financial distress sebesar 0.310. Jika LDR, ukuran dewan direksi, dan CAR dianggap konstan, maka log of odds yang mendapati financial distress turun menjadi 0.469 , karena nilai $\beta$ negatif. Setiap kenaikan satu CAR menurunkan log of odds bank yang mengalami financial distress sebesar 0.469. Jika LDR, ukuran dewan direksi, dan NIM dianggap konstan, maka log of odds yang mendapati financial distress turun menjadi 0.132 , karena nilai $\beta$ negatif.

\section{Pengaruh Variabel Risk Profile yang Diproksikan dengan NPL terhadap Financial Distress}


Signifikansi non performing loan (NPL) pada tabel. 3 mendeskripsikan H1 ditolak, maknanya tidak ada pengaruh antara NPL dengan financial distress. Sehingga, penelitian ini tidak sejalan dengan signaling theory di mana NPL rendah atau tinggi akan mengirimkan sinyal positif atau negatif terhadap pihak ekternal yang berkepentingan sehingga dapat mengambil langkah ingin menginvestasikan dananya atau tidak pada bank tersebut (Harahap, 2015). Menurut pendapat Sistiyarini \& Supriyono (2017) apabila nilai NPL bank tinggi akan tetapi diikuti oleh modal yang kuat dari bank maka risiko-risiko kredit bermasalah masih bias diatasi. Selain itu, nilai rata-rata NPL pada BUSN non devisa tidak melebihi batas ketentuan $5 \%$ yaitu sebesar 2,88 yang mengindikasikan masih pada batas aman. Salah satunya, bank Victoria Internasional tahun 2017 tergolong dalam financial distress berdasarkan bankometer model padahal memiliki NPL 1,56\%. Rendahnya nilai NPL namun tergolong financial distress sebagai akibat nilai kecukupan modal mendapati penurunan $6,41 \%$. Hasil penelitian ini sejalan dengan Harahap (2015), Kuncoro \& Agustina (2017), Nufus et al., (2018).

\section{Pengaruh Variabel Risk Profile yang Diproksikan dengan LDR terhadap Financial Distress}

Signifikansi loan to deposit ratio (LDR) pada tabel. 3 mendeskripsikan $\mathrm{H} 2$ diterima, maknanya terdapat pengaruh LDR dengan financial distress. Nilai $\beta$ pada tabel. 3 menunjukkan arah hubungan negatif, di mana semakin tinggi LDR timbulnya potensi terjadi financial distress semakin kecil. Penelitian ini selaras dengan signaling theory, ketika bank memiliki aktiva yang cukup likuid namun bank juga menyalurkan kredit kepada pihak eksternal dengan jumlah besar, disisi lain dana pihak ketiga yang dihimpun ternyata sedikit, maka pihak eksternal dapat menyimpulkan bahwa kemampuan bank dalam menjaga likuiditasnya terjaga, sehingga kemungkinan bank mengalami financial distress juga rendah (Susanto \& Njit, 2012). Selain itu, nilai LDR yang tinggi membuat dana yang dihimpun bank lebih banyak daripada dana yang disalurkan dalam bentuk kredit. Sehingga terdapat dana mengendap sebagai simpanan apabila nasabah ingin menarik kembali uangnya (Sumantri \& Jurnali, 2010). Penelitian yang mendukung hasil ini yaitu Sumantri \& Jurnali (2010), Susanto \& Njit (2012).

\section{Pengaruh Variabel Good Corporate Governance yang Diproksikan dengan Ukuran Dewan Direksi terhadap Financial Distress}

Signifikansi ukuran dewan direksi pada tabel. 3 mendeskripsikan H3 diterima, artinya terdapat pengaruh ukuran dewan direksi dengan financial distress. Nilai $\beta$ pada tabel. 3 menunjukkan arah hubungan positif, di mana semakin banyak ukuran dewan direksi menimbulkan potensi financial distress semakin besar. Dalam studi yang dilakukan hubungan ukuran dewan direksi dan financial distress didasari atas agency theory yang menjelaskan principal (pemilik/pemegang saham) dengan agent (pelaksana/manajer) terdapat suatu kontrak pemisahan yang mana akan menimbulkan agency problem (Setiawan et al., 2016). Pelaksana seringkali bertindak bertentangan dengan keinginan atau harapan yang ingin dicapai oleh pemiliki sehingga timbulnya perbedaan kepentingan. Apabila hal ini dibiarkan dapat meningkatkan agency cost sehingga semakin besar jumlah dewan direksi akan mempengaruhi lamanya penyelesaian permasalahan karena masih dikomunikasikan dan dikoordinasikan dengan dewan direksi lain. Selain itu, tugas dewan direksi untuk mengendalikan manajemen dan mengelola bank akan terganggu sehingga kondisi bank tidak likuid terhadap kewajibannya dan kemungkinan mengalami financial distress semakin tinggi (Siagian, 2010). Penelitian yang mendukung hasil ini anatara lain Helena \& Saifi (2018), John \& Ogechukwu (2018).

\section{Pengaruh Variabel Good Corporate Governance yang Diproksikan dengan Komisaris Independen terhadap Financial Distress}

Signifikansi komisaris independen pada tabel. 3 mendeskripsikan H4 ditolak, menandakan tidak adanya pengaruh komisaris independen dengan financial distress. Hubungan antara proporsi komisaris indepeden terhadap financial distress berdasar agency theory, namun hasil penelitian tidak mendukung agency theory yang menyatakan komisaris independen memiliki fungsi selaku supervisory board menjadi sangat vital dalam menyeleksi atau memantau setiap kebijakan yang ada. Terkadang komisaris independen juga tidak memiliki perilaku independensi yang baik dan keberadaannya hanya sebagai formalitas sehingga sistem pengendalian yang seharusnya dikerjakan komisaris independen tidak berlangsung efektif dan fungsi monitoring yang seharusnya dilakukan untuk mengawasi kebijakan direksi hanya sebatas pemenuhan kebutuhan belaka. Contoh pada Bank Syariah Bukopin tahun 2016 mempunyai komisaris indepen 2 dari total 4 yang telah menyanggupi ketentuan Bank Indonesia akan 
tetapi tergolong financial distress berdasar bankometer model. Setelah ditelusuri, tahun tersebut mengalami kerugian pendapatan bunga hingga -1,67\%. Helena \& Saifi (2018), Radifan et al., (2015), Setiawan et al., (2016) mendukung hasil penelitian ini.

\section{Pengaruh Variabel Earning yang Diproksikan dengan ROA terhadap Financial Distress}

Signifikansi return on asset (ROA) pada tabel. 3 mendeskripsikan H5 ditolak, artinya tidak ada pengaruh antara ROA dengan financial distress. Sebelumnya telah dijelaskan, dalam penelitian ini hubungan antara ROA dengan financial distress didasari atas signalling theory, namun hasil penelitian ini tidak mendukung signalling theory yang menyatakan bahwa laporan keuangan akan mencantumkan sinyal positif ataupun sinyal negatif kepada pemakai atau stakeholder. Alasan tidak berpengaruhnya ROA yakni Bank Indonesia sebagai pembina dan pengawas perbankan lebih mementingkan nilai profitabilitas suatu bank yang diukur dari asset dengan sebagian besar dananya berasal dari dana simpanan masyarakat. Hal ini membuat adanya pertarungan suku bunga kredit antar sesama BUSN non devisa dalam memperoleh nasabah debitur sehingga memiliki kecenderungan pembagian suku bunga yang serupa. Contoh Bank Harda Internasional tahun 2018 mempunyai nilai ROA -5,34\% namun berdasarkan bankometer model termasuk pada non-financial distress. Ternyata, pada tahun tersebut Bank harda Internasional mengoptimalkan sisi pendapatan bunga bersih hingga 1\%. Nufus et al., (2018), Ramadhani (2019), Sistiyarini \& Supriyono (2017) mendukung hasil tidak ada pengaruh ROA terhadap financial distress.

\section{Pengaruh Variabel Earning yang Diproksikan dengan ROE terhadap Financial Distress}

Signifikansi return on equity (ROE) pada tabel. 3 mendeskripsikan H6 ditolak, artinya tidak ada pengaruh antara ROE dengan financial distress. Hubungan antara ROE dengan financial distress didasari atas signalling theory, namun hasil penelitian ini tidak mendukung signalling theory yang menyatakan bahwa pihak manajemen (pemberi sinyal) akan melaporkan kondisi keuangan bank kepada stakeholder (penerima sinyal). Alasan tidak adanya pengaruh karena semakin tinggi laba yang diperoleh maka meningkatkan kewajiban penyediaan modal minimum. Jika situasi ini dibiarkan dapat mengganggu bank dalam ekspansif operasinya karena modal yang disediakan terlalu besar. Contoh pada bank Yudha Bhakti tahun 2018 di mana memiliki nilai minus pada ROE namun berdasar bankometer model tergolong non-financial distress. Setelah ditelusuri, ternyata bank tersebut memiliki pengoptimalan laba lain yaitu dari penyaluran kredit yang meningkat dari tahun sebelumnya. Kurniasari \& Ghozali (2013), Sumantri \& Jurnali (2010) mendukung hasil penelitian ini.

\section{Pengaruh Variabel Earning yang Diproksikan dengan BOPO terhadap Financial Distress}

Signifikansi return on equity (ROE) pada tabel. 3 mendeskripsikan H7 ditolak, artinya tidak ada pengaruh antara BOPO dengan financial distress. Hubungan antara BOPO dengan financial distress didasari atas signalling theory, namun hasil penelitian ini tidak mendukung signalling theory yang menyatakan bahwa pihak eksekutif perusahaan memiliki informasi yang baik terkait perusahaannya akan menyampaikan informasi tersebut ke pihak eksternal sehingga pihak eksternal mau menanamkan modalnya kepada perusahaan (Susanto \& Njit, 2012). Apabila nilai dari pendapatan lebih kecil daripada beban maka dapat mengurangi kinerja daripada perbankan itu sendiri (Theodorus \& Artini, 2018). Apabila rata-rata suatu jenis bank menunjukkan hasil yang baik dari segi BOPO mengindikasikan bahwa efisiensi yang dilakukan juga baik. Terlihat pada nilai rata-rata hasil deskriptif yang menunjukkan 91,06\% lebih kecil daripada ketentuan Bank Indonesia sebesar 97\%. Contoh bank Artos tahun 2015 mempunyai nilai 101,17\% akan tetapi pada bankometer model tergolong non-financial distress. Penyebab bank tersebut tidak tergolong distress karena berhasil mengoptimalkan pendapatan bunga dan menekan kredit bermasalah. Penelitian yang mendukung tidak adanya pengaruh BOPO terhadap financial distress Kriswanto (2019), Nufus et al., (2018), Ramadhani (2019).

\section{Pengaruh Variabel Earning yang Diproksikan dengan NIM terhadap Financial Distress}

Signifikansi net interest margin (NIM) pada tabel 3 mendeskripsikan H8 diterima, artinya terdapat pengaruh NIM dengan financial distress. Nilai $\beta$ pada tabel. 3 menunjukkan arah hubungan negatif, di mana semakin tinggi NIM timbulnya potensi terjadi financial distress semakin kecil. Penelitian ini mendukung hubungan NIM dan financial distress yang berdasar signaling theory, di mana jika dari sisi 
Rista Nurfadila Pristianti \& Musdholifah. Pengaruh Risk Based Bank Rating terhadap Financial Distress pada BUSN Non Devisa

pendapatan bunga bersih yang diterima bank atau NIM ternyata menunjukkan nilai yang cukup baik dan tidak berada pada posisi rugi, maka pihak luar akan percaya bahwa menaruh investasi pada bank tersebut juga bias menghasikan keuntungan yang besar (Sadida, 2018). Meningkatnya pendapatan bunga bersih mengindikasikan kondisi kredit lancar lebih besar dibandingkan dengan kredit bermasalah. Hal ini membuat pengembalian upah yang dikelola oleh bank berasal dari aset berisiko juga akan semakin tinggi sehingga kecil peluang mendapati financial distress. Asyikin et al., (2018), Shidiq \& Wibowo (2017) mendukung adanya hubungan negatif signifikan NIM terhadap financial distress.

\section{Pengaruh Variabel Capital yang Diproksikan dengan CAR terhadap Financial Distress}

Signifikansi capital adequacy ratio (CAR) pada tabel. 3 mendeskripsikan H9 diterima, artinya terdapat pengaruh CAR dengan financial distress. Nilai $\beta$ pada tabel. 3 menunjukkan arah hubungan negatif, di mana semakin tinggi CAR timbulnya potensi terjadi financial distress semakin kecil. Hubungan antara CAR dan financial distress sejalan dengan signaling theory yang menjelaskan jika investor melihat modal bank cukup besar, baik modal inti ataupun pelengkap, maka investor akan berasumsi bank dapat menyelesaikan segala risiko yang mungkin terjadi terutama risiko kredit (Halim, 2016). Sehingga investor akan menaruh kepercayaan kepada bank karena kemungkinan mengalami kondisi financial distress semakin kecil. Modal menjadi komponen terpenting dalam menutupi segala kemungkinan risiko yang timbul dari penanaman dana dalam aktiva produktiv yang mengandung risiko. Modal yang tinggi akan mengamankan bank dari munculnya risiko yang dapat mengakibatkan bank mengalami kesulitan keungan sehingga bisa digunakan sebagai sistem peringatan awal sebelum terjadinya kesulitan keuangan (Kuncoro \& Agustina, 2017). Hasil penelitian ini sejalan dengan Asyikin et al., (2018), Hidayati (2015).

\section{KESIMPULAN}

Studi yang dilakukan menghasilkan NPL tidak berpengaruh terhadap financial distress sebagai akibat rata-rata NPL BUSN non devisa masih aman. Selanjutnya, LDR memiliki pengaruh negatif signifikan terhadap financial distress. Oleh sebab itu bank wajib mengendalikan likuiditas terutama dari segi kredit yang diberikan. Sedangkan, ukuran dewan direksi terdapat pengaruh positif signifikan terhadap financial distress sehingga bank harus memperhatikan peranan dewan direksi agar tidak hanya memikirkan koordinasi dan komuniaksi antar sesama dewan direksi. Lain halnya dengan komisaris independen yang tidak berpengaruh terhadap financial distress sebagai akibat kurangnya implementasi pengendalian serta adanya komisaris independen hanya sebatas formalitas. Variabel ROA dan ROE menghasilkan tidak berpengaruh terhadap financial distress. Penyebabnya ialah laba tinggi meningkatkan kewajiban penyediaan modal minimum sehingga BUSN non devisa tidak bisa ekspansif dalam menjalankan operasinya. Selanjutnya, BOPO juga tidak berpengaruh terhadap financial distress sebagai akibat rata-rata BOPO BUSN non devisa sudah menyanggupi ketentuan Bank Indonesia. Adanya pengaruh negatif signifikan NIM terhadap financial distress membuat bank wajib menjaga kualitas daripada kredit yang diberikan agar dapat memperoleh pendapatan bunga yang maksimal. Sedangkan, dari sisi CAR berpengaruh negatif signifikan, sehingga bank wajib mengelola kecukupan modal yang dimiliki dan mengendalikan aset berisiko baik dari kredit atau dari administrasi.

Penelitian ini fokus dengan batasan bankometer model dalam menilai financial distress pada BUSN non devisa tahun 2013-2018. Disamping itu, variabel yang digunakan hanya sisi internal bank (risk based bank rating) tanpa memperhitungkan kondisi eksternal atau makroekonomi. Oleh sebab itu, penelitian selanjutnya dapat menggunakan rasio lainnya pada bank seperti current ratio, net profit margin, suku bunga, atau inflasi. Penelitian selanjutnya juga dapat memanfaatkan model prediksi financial distress dapat dengan membandingkan beberapa model lainnya, seperti Grover, Altman, Ohlson, dan Foster agar perolehan hasil prediksi lebih akurat serta menambah tahun penelitian dan menggunakan perbandingan dengan bank sejenis seperti BUSN Devisa.

\section{DAFTAR PUSTAKA}

Assaji, J. P., \& Machmuddah, Z. (2017). Rasio Keuangan dan Prediksi Financial Distress. Jurnal 
Penelitian Ekonomi Dan Bisnis, 2(2), 58-67.

Asyikin, J., Chandrarin, G., \& Harmono. (2018). Analysis Of Financial Performance To Predict Financial Distress In Sharia Commercial Banks In Indonesia. International Journal of Accounting, Finance, and Economics, 1(2), 11-20.

Bank Indonesia. (2011). Surat Edaran Bank Umum Konvensional di Indonesia Perihal Penilaian Tingkat Kesehatan Bank Umum. www.bi.go.id (diakses pada tanggal 19 November 2019)

Brigham, E. F., \& Houston, J. F. (2009). Fundamentals of Financial Management. South-Western Cengage Learning.

Erari, A., Salim, U., Idrus, M. S., \& Djumahir. (2013). Financial Performance Analysis of PT. Bank Papua: Application of Cael, Z-Score and Bankometer. IOSR Journal of Business and Management, 7(5), 8-16.

Fadhilah, F. N., \& Syafruddin, M. (2013). Analisis Pengaruh Karakteristik Corporate Governance Terhadap Kemungkinan Financial Distress. Diponegoro Journal of Accounting, 2(2), 1-15.

Fathonah, A. N. (2016). Pengaruh Penerapan Good Corporate Governance Terhadap Financial Distress Sektor Property, Real Estate Dan Konstruksi Bangunan. Jurnal Ilmiah Akuntansi, 1(2), 133-150.

Firmasnyah, B. (2018). 10 Krisis Moneter Terburuk Sepanjang Sejarah Dunia. Koran Sindo. https://ekbis.sindonews.com/read/1312104/180/10-krisis-moneter-terburuk-sepanjang-sejarahdunia-1528277126 (diakses pada tanggal 2 Desember 2019)

Ghozali, I. (2018). Aplikasi Analisis Multivariate dengan Program IBM SPSS 25. Badan Penerbit Universitas Diponegoro.

Halim, C. (2016). Analisis Pengaruh Rasio Keuangan dan Market Effect untuk Memprediksi Kebangkrutan Bank Menggunakan Model Regresi Logistik. Jurnal Online Mahasiswa Fakultas Ekonomi Universitas Riau, 3(1), 1294-1308.

Hanafi, J., \& Breliastiti, R. (2016). Peran Mekanisme Good Corporate Governance dalam Mencegah Perusahaan Mengalami Financial Distress. Jurnal Online Insan Akuntan, 1(1), 195-220.

Harahap, A. M. (2015). Prediction of Financial Distress in Foreign Exchange Banking Firms Using Risk Analysis, Good Corporate Governance, Earnings, and Capital. The Indonesian Accounting Review, 5(1), 33-44.

Hayati, W. (2018). Pengaruh Capital Adequancy Ratio, Net Interest Margin, Leverage dan Bank Size Terhadap Financial Distress Bank Umum di Indonesia Tahun 2009-2016. Jurnal Ilmiah Mahasiswa FEB, 6(2), 1-17.

Helena, S., \& Saifi, M. (2018). Pengaruh Corporate Governance Terhadap Financial Distress. Jurnal Administrasi Bisnis (JAB), 60(2), 103-112.

Hidayati, L. N. (2015). Pengaruh Kecukupan Modal (CAR), Pengelolaan Kredit (NPL), dan Likuiditas Bank (LDR) Terhadap Probabilitas Kebangkrutan Bank. Jurnal Ilmu Manajemen, 12(1), 38-50.

Hilmy, H., Mohd, S. A., \& Fahmi, N. A. (2013). Factors Affecting Bankruptcy: the Case of Malaysia. International Journal of Undergraduates Studies, 2(3), 4-8.

Indonesia Stock Exchange. 2013-2018. Laporan Keuangan Tahunan. www.idx.co.id (diakses pada tanggal 18 Desember 2019) 
Rista Nurfadila Pristianti \& Musdholifah. Pengaruh Risk Based Bank Rating terhadap Financial Distress pada BUSN Non Devisa

Iqbal, M., Riyadi, S., Sabrianti, P., \& Afidah, A. N. (2018). Pemetaan Tingkat Kesulitan Keuangan Bank Syariah Di Indonesia. Jurnal Economia, 14(2), 138-157.

John, A. T., \& Ogechukwu, O. L. (2018). Corporate Governance and Financial Distress in the Banking Industry: Nigerian Experience. Journal of Economics and Behavioral Studies, 10(1), 182-193.

Kristanti, F. T. (2014). Prediksi Kebangkrutan Bank-Bank yang Terdaftar di Bursa Efek Indonesia. Jurnal Keuangan Dan Perbankan, 18(1), 130-138.

Kriswanto, H. (2019). Financial Performance and Macro Economic Environment as Predictors of Financial Distress National Private Banks in Indonesia. International Journal of Economics, Business, and Management Research, 3(10), 58-71.

Kuncoro, S., \& Agustina, L. (2017). Factors to Predict The Financial Distress Condition of the Banking Listed in The Indonesia Stock Exchange. Accounting Analysis Journal, 6(1), 39-47.

Kurniasari, C., \& Ghozali, I. (2013). Analisis Pengaruh Rasio CAMELDalam Memprediksi Financial Distress Perbankan Indonesia. Diponegoro Journal of Accounting, 2(4), 1-10.

Lestarini, A. H. (2010). Penyelamatan Krisis Perbankan 2008 Versi BI. Oke Finance. https://economy.okezone.com/read/2010/01/18/320/295127/penyelamatan-krisis-perbankan2008-versi-bi (diakses pada tanggal 2 Desember 2019)

Makki, S. (2019). Meroket Dari 2017, Kredit Bank 2018 Capai 12,88 Persen. https://www.cnnindonesia.com/ekonomi/20190111190953-78-360264/meroket-dari-2017kredit-bank-2018-capai-1288-persen (diakses pada tanggal 2 Desember 2019)

Murhadi, W. R., Tanugara, F., \& Sutejo, B. S. (2018). The Influence of Good Corporate Governance (GCG) on Financial Distress. Advances in Social Science, Education and Humanities Research (ASSEHR), 186(15), 76-79.

Nufus, K., Audina, N., \& Muchtar, A. (2018). Effect of Financial Distress Ratio Banking Company in Indonesia Period 2011-2015. Research Journal of Finance and Accounting, 9(16), 68-75.

Nuranto, A. A., \& Ardiansari, A. (2017). Pengaruh Rasio Keuangan, Firm Size, dan Market Effect Terhadap Tingkat Kebangkrutan. Management Analysis Journal, 6(2), 185-194.

Pasaribu, R. B. F., Kowanda, D., \& Firdaus, M. (2015). Financial Distress Prediction on Public Listed Banks in Indonesia Stock Exchange. Proceedings of the 3rd International Congress on Interdisciplinary Behavior and Social Sciences, ICIBSoS 2014 (Issue September 2017).

Prasidha, K. D., \& Wahyudi, S. T. (2015). Dampak Nilai Tukar dan Risk-Based Bank Rating Terhadap Prediksi Kondisi Perbankan Indonesia. QE Journal, 04(03), 122-142.

Purwohandoko, Asandimitra, N., Isbanah, Y., \& Kautsar, A. (2014). Dasar-dasar Manajemen Keuangan (Teori, Aplikasi dan Kasus). Universitas Negeri Surabaya.

Radifan, R., Nur, E., \& Yuyetta, A. (2015). Analisis Pengaruh Mekanisme Good Corporate Governance Terhadap Kemungkinan Financial Distress. Diponegoro Journal of Accounting, 4(3), 1-11.

Rahman, R. A., \& Masngut, M. Y. (2014). The Use of "CAMELS" in Detecting Financial Distress of Islamic Banks in Malaysia. Journal of Applied Business Research, 30(2), 445-452.

Rahman, Z. (2017). Financial Soundness Evaluation of Selected Commercial Banks in Bangladesh: An Application of Bankometer Model. Journal of Finance and Marketing, 8(2), 63-70. 
Ramadhani, U. (2019). Prediction Model of Financial Distress Based on Financial Performance of Conventional Go-Public Banks in Indonesia. Everant Publisher Pvt. Ltd. Management and Economic Journal, 3(490), 490-504.

Restianti, T., \& Agustina, L. (2018). The Effect of Financial Ratios on Financial Distress Conditions in Sub Industrial Sector Company. Accounting Analysis Journal, 7(1), 25-33.

Sadida, B. D. (2018). Risk Profile, Good Corporate Governance, Earnings, and Capital ( RGEC ) Sebagai Prediktor Terhadap Kondisi Financial Distress Pada Perusahaan Perbankan. Jurnal Manajemen Dan Bisnis Indonesia, 7(4), 347-357.

Setiawan, A., Sukarmanto, E., \& Fadilah, S. (2016). Pengaruh Ukuran Dewan Direksi , Ukuran Dewan Komisaris , Komisaris Independen, Kepemilikan Manajerial dan Kepemilikan Institusional terhadap Financial Distress. Prosiding Akuntansi, 2(1), 285-292 ISSN: 2460-6561.

Shar, A. H. (2010). Performance Evaluation of Banking Sector in Pakistan: An Application of Bankometer. International Journal of Business and Management, 5(9), 81-86.

Shidiq, I., \& Wibowo, B. (2017). Prediksi Financial Distress Bank Umum di Indonesia: Analisis Diskriminan dan Regresi Logistik. Esensi : Jurnal Bisnis Dan Manajemen, 7(1), 27-40.

Siagian, D. (2010). Analisis Pengaruh Struktur Corporate Governance Terhadap Perusahaan yang Mengalami Financial Distress. Media Riset Akuntansi, Auditing, \& Informasi, 10(3), 46-64.

Sistiyarini, E., \& Supriyono, S. E. (2017). The Application of Risk Based Bank Rating on Bankruptcy Prediction of Banks in Indonesia. Jurnal Keuangan Dan Perbankan, 21(2), 302-311.

Sofiasani, G., \& Gautama, B. P. (2016). Pengaruh CAMEL Terhadap Financial Distress Pada Sektor Perbankan Indonesia Periode 2009-2013. Journal of Business Management and Enterpreneurship Education, 1(1), 136-146.

Sumantri, \& Jurnali, T. (2010). Manfaat Rasio Keuangan Dalam Meprediksi Kepailitan Bank Nasional. Jurnal Bisnis Dan Akuntansi, 12(1), 39-52.

Susanto, Y. K., \& Njit, T. F. (2012). Penentu Kesehatan Perbankan. Jurnal Bisnis Dan Akuntansi, 14(2), $105-116$.

Theodorus, S., \& Artini, L. G. S. (2018). Studi Financial Distress Pada Perusahaan Perbankan di BEI. E-Jurnal Manajemen Unud, 7(5), 2710-2732.

Yacheva, N., Saifi, M., \& Z.A, Z. (2016). Analisis Tingkat Kesehatan Bank Dengan Metode RBBR (Risk-Based Bank Rating) (Studi Pada Bank Umum Swasta Nasional Devisa yang Terdaftar di Bursa Efek Indonesia Periode 2012-2014). Jurnal Administrasi Bisnis, 37(1), 37-45.

Yamin, I. Y., \& Sami, A. M. M. (2016). Evaluating the Financial Soundness of the Jordanian Commercial Banks by Applying BankoMeter' s Model. Research Journal of Finance and Accounting, 7(2), 124-130. 